TITLE:

\title{
The Last Day with Nishida-san
}

$\operatorname{AUTHOR}(S)$ :

Nakamura, Michio

\section{CITATION:}

Nakamura, Michio. The Last Day with Nishida-san. Pan Africa News 2011, 18(special issue): 10-10

ISSUE DATE:

2011-09

URL:

http://hdl.handle.net/2433/147280

RIGHT:

Copyright (C) Pan Africa News. 
estimated to be her father, did." This might be too small a finding to mark the finale of such a great chimpanzee researcher, but in a sense, it was indicative of the passion he always displayed when watching chimpanzees. He described this himself in a chapter of The Great Ape Project (1993), "Chimpanzees are always new to me!"

One day, we went on a safari to Katumbi and Buhingu in the northern area of the park. At that time, the Embassy of Japan in Tanzania was planning to build a dispensary in Katumbi. The main purpose of our safari was to hear the opinion of the Katumbi people, to inspect the building site, and to make a report to the Embassy. We visited Katumbi Primary School and met lively students there. This school was built by collaboration of the Mahale Wildlife Conservation Society and the Embassy under the Grant Assistance for Grassroots Projects (2001). But Nishidasan seemed shocked to see the wretched condition of the school and took many photos. There were only four teachers for over 800 students. There were not enough desks. The floors of the classrooms were full of holes.

While Nishida-san was staying in Kansyana, he was always in a good mood. Every night, he enjoyed a little beer with fish from Lake Tanganyika, tough chicken and goat. After dinner, we went on to the next routine, gossiping about chimpanzees and humans. For example, we exchanged our observations about the idiosyncratic ways different alpha males shared meat and copulated. We had a good time, occasionally bursting into laughter. Twenty long years seem to have erased my inhibitions.

On the morning of August 27, 2009, when Nishidasan left Mahale last time, only I saw him off at Kasiha Beach. In the old days, many inhabitants of Kasiha gathered to say farewell to researchers going back to their countries. Now that the park administration controls the people who can stay in the park, we could not expect such a scene. The boat full of eco-tourists picked up Nishidasan and steered its course northward. It soon drifted out of sight. He gazed at Kasoje Forest in front and Mt. Nkungwe behind, the highest peak in the Mahale Mountains chain. I can no longer ask him if he reminisced about the pioneering days he spent there 44 years before or if he planned to come again next year.

\section{The Last Day with Nishida-san}

\section{Michio Nakamura \\ Kyoto University, Japan}

On 27th May, 2011, about ten days before he passed away, I visited Nishida-san at his home. I visited him because I had received a message from him that he wanted to hand over several things about Mahale. Eventually, this visit became my last opportunity to see him alive.

I had not visited him for about a month then, as I had been busy in April and May occupied with teaching duties to new master course students. Nishida-san was much thinner than a month before and looked very small. When I arrived, he first apologized about staying in bed while talking to me. "I am deaf of one ear" told he. But he conversed logically and clearly.

He told me one by one, sometimes making a pause as if he was trying to remember everything that he needed to tell me, about long-term data of Mahale from the early period, about his own data that had been input into computer but had not been published, and about his forthcoming English book "Chimpanzees of the Lakeshore" that became his final work. He was really a researcher until the very final stage of his life.

Finally, he expressed his concern about research assistants at Mahale. He asked me to think about supporting the post-retirement years of some assistants from the early days. I realized again how Nishida-san appreciated the contributions made by the Tongwe people for continuing the research at Mahale over 40 years.

\section{Prof. Nishida and Ntologi}

\section{Noriko Itoh \\ Kyoto University, Japan}

In 1995, I first visited Mahale. That was the year when Ntologi died. This happening left a vivid impression on me about Prof. Nishida: how deeply he was attached to chimpanzees and how deeply the local people understood it. When Ntologi was found dying in the forest, he did not hesitate to intervene between Ntologi and the other adult male who made several approaches. I was not aware how depressed he was when Ntologi died next morning and he collected necessary data from the body. But after finishing his tasks, he expressed his feelings and even said that he was discouraged from observing chimpanzees any more. I could not find any words for him. Ntologi died around $3 \mathrm{AM}$ and it was his wife that noticed the change in his condition, watching over him all night. Later, the wives of field assistants came to the camp together expressing their condolences to Prof. Nishida and his wife. Such an event happened only once in my memory. People understood Prof. Nishida's attachment to individual chimpanzees, since he talked about chimpanzees to anyone pleasantly and passionately. I believe such local people's understanding acted as the firm base for his accomplishments. I did not expect that we would lose our opportunity to hear his fascinating chimpanzee talks, often with a hearty laugh, so suddenly. There is another story about the death of Ntologi, but I keep it for later. May his soul rest in peace.

\section{Dr. Toshisada Nishida and His Video Record of Chimpanzees}

\section{Koichiro Zamma \\ Great Ape Research Institute, Hayashibara, Japan}

I am presently in the forest of Mahale, where I am writing this essay. Dr. T. Nishida is not here, but his habituated chimpanzees and field station remain.

In August 1999, Dr. Nishida brought me to Mahale for my first study of wild chimpanzees. This was when he started to use a digital video camera for his fieldwork. Since then, video data have become one of the necessaries of his research. I also used a video camera and focused on grooming behavior as my main subject, but Dr. Nishida seems to have recorded everything about chimpanzees in Mahale. When he followed chimpanzees, he always used his video camera and recorded feeding, displays, hunting, 